Original scientific article

UDC: $616.981 .45-036.22(439-89) " 1738 / 1739 "$

614.4(439-89)"17"

228298764

DOI 10.25106/AHM.2016.1111

\author{
Nenad Ninković \\ Goran Vasin \\ History department \\ Faculty of Philosophy, University of Novi Sad \\ Dr Zorana Đinđića 1, 21000 Novi Sad, Serbia \\ E-mail: goran.vasin@ff.uns.ac.rs \\ nenadninkovich@yahoo.com
}

\title{
MICROUNITS TABAN, SENTANREJA AND POMAZ AS A PARADIGM OF FIGHTING PLAGUE EPIDEMIC 1738-1739*
}

\begin{abstract}
The plague in history left many consequences on society, not just on population itself, but also in cultural, sociological and psychological sense. Although way to cure it was unknown for a long time, in time it was noticed that isolating infected persons, settlements or areas diminish destructive effects of the disease, but despite that knowledge in severe epidemics it was difficult to isolate settlements, and that amplified consequences. The plague that spread from Ottoman Empire into Habsburg monarchy during their war (1737-1739) caused serious problems in Hungarian territory. Serbs, who lived there and fought the war as Austrian soldiers, were engulfed by that epidemic that spread outside area of direct battles and military camps. This paper shows what fighting against this epidemic looked like in the microunits - Taban, i.e. Serbian part of Budim (Buda), Sentandreja (Szentendre) and village of Pomaz, what were differences between them, how they were isolated and where epidemics left strongest marks. Paper is primarily based on unpublished archive materials from Fond "B" of Archive of Serbian Academy of Science and Art in Sremski Karlovci, mostly written by priests to Budim bishop Vasilije Dimitrijević.
\end{abstract}

Key Words: plague, quarantine

Non MeSH: Taban, Sentandreja, Pomaz, bishop Vasilije Dimitrijević

\footnotetext{
* This paper is realized on the research project Territory of Vojvodina in context of European history, OI 177002, financed by Ministry of Education, Science and Technological Development of The Republic of Serbia.
} 
Large upheavals, wars and epidemics were always leaving dire mark, the one that historians can follow through historical sources and use them as a basis for pointing out what processes and issues a society faced then. Diseases that human civilization couldn't cure for a long time were threat that caused use of different, often radical, measures, and plague epidemic that appeared in Habsburg monarchy in 1737 and lasted in certain regions all the way to 1744 , for its possible consequences to society was a topic that made both contemporaries and historians think and write about it. In modern Hungarian historiography it is subject of study of several historians (Vekerdi, David, Öri, Kun). Foreign and Serbian historians particularly focused on epidemic development in Banat, Srem and Belgrade, but were also looking at wider picture, even outside the Monarchy (S. Pecinjački, S. Gavrilović, J. Ilić, D. J. Popović, Ž. Sečanski, M. Kocić, H. Dajč). In historiography a special place was given to epidemic that hit Serbian population in Taban, foremost out of pen of Dušan J. Popović who, in the monograph Serbs in Budim, on the basis of voluminous letters of priests constructed valid conclusions on Serbs ordeal and assumptions on issues that were brought about in Budim vicinity. In his writings Popović used several documents, those exclusively related to Budim, and for that reason part of archive material remained unused. His interpretations and comparisons to already known data give more comprehensive picture of fate of population of three settlements in small region near Danube right bank - Taban, Sentandreja and Pomaz. ${ }^{1}$

Plague is communicable disease from zoonozes group and in history of civilization was one of most dangerous epidemic diseases with extremely high fatality rate. It is caused by bacteria Yersinia pestis, and is best known in a form of bubonic plague, named after swollen glands. Incubation lasts between two and five days, then first signs of disease appear - fever and high body temperature, sometimes also rapid heart beat and hypertension. Soon afterwards lymph glands expand with high body temperature and fever, and often severe headache. Further development of the disease brings coughing, soon afterwards with blood in sputum, and eventually sepsis and death, something that can occur within just 48 hours after first visible symptoms of the disease. Today it is known that treatment should be started as soon as possible, preferably in first 24 hours, by administering streptomycin, and it should be noted that patient isolation is of great importance [1-4].

For centuries the plague was a disease with extremely high mortality rate. In Habsburg monarchy in 18th century it occurred on several occasions. It was mostly

1 Taban was a part of Budim populated almost exclusively by Serbs that arrived there at the time of Great Exodus (1690), and was situated in a space between Gelert hill and Budim fortress. It was mostly populated by merchants and artisans, organized into guilds, and altogether into Serbian community. Not far from Budapest, towards north and on Danube bank, is situated village of Pomaz, some ten kilometres from capital of Hungary, and it was also populated by Serbs at the time of Exodus (1690). Further nortwards along the Danube, one arrives to the third settlement significant for study of plague epidemic 1738-1739, Sentandreja, that at the time was town populated primarily by Serb artisans and merchants, and was also a seat of Budim bishop. All settlements mentioned here are on the right bank of the Danube, in the plain overlooked by Piliška hills. 
transferred from Ottoman Empire, and therefore Pestpatent of 1710 and Pestordnung from 1713 prohibited all exchange with Ottoman Empire at times when epidemic was in progress. Especially important role in preventing infection spreading in the Monarchy had emperor Karl (Charles) VI (1711-1740) and his daughter Maria Theresa (1740-1780) [5-7]. Plague epidemic of large scale in Habsburg monarchy occurred between 1738 and 1741. On that occasion disease appeared in several parts of the state, first in the east in Erdély region (Transylvania) at the end of 1737 and the beginning of 1738, where it was brought by soldiers retreating from Ottoman territory. Already in February 1738 it appeared in Temišvar (Timișoara), and from beginning of 1739 it advanced to central part of Hungary, to Danube and Tisa basins. Having in mind that contemporaries were aware that increased fluctuation of population enhance spreading of the disease, under circumstances the only solution was closing of settlements, i.e. putting guards on settlement entrances. Besides, needed were doctors to check up suspected or infected persons and confine them into quarantines, but shortage of medical personnel complicated this task. Consequently, their presence was visible in cities and towns, but not in villages. On the other hand, citizens huddled into narrow streets considered their inability to move as imprisonment, especially when it coincided with a ban of religious worship and church gatherings, and uneducated considered that to be deprivation of religious rights. Also, lack of discipline of urban population was boosted by existential reasons, for ban of movement prevented trade and made farming difficult, so food was reaching cities barely or not at all, and fuel supplies for winter months were hard to obtain. For that reason they considered physicians to be problem, they blamed them for inability to move, and riots occurred in several urban settlements, even killings of medical personnel (in Budim and Debrecen). That resulted in even harder situation and facilitated spreading of epidemic. [8-13]. Casualties in period 1738-1741 totaled approximately 250,000 dead, which made some $5 \%$ of entire population of Hungary. On the other hand, there were some settlements or smaller regions where casualties were much larger, for instance Banat. That brought a series of personal tragedies whose consequences were felt in families for many years. [14-17]

Different protection from plague can be seen on example of three settlements, Taban, Sentandreja and Pomaz, that, although situated next to each other had different fate during the epidemic. Reconstruction of events is possible by virtue of letters sent to Budim bishop Vasilije Dimitrijević (1728-1748), who was absent from eparchy because of various profane tasks. The letters were not created to describe epidemic, rather a state of economy in Sentandreja and Sečuj (Dunaszekcsö), resident places of bishops, but due to severity of situation they contain quite a lot of data regarding life during the plague, fighting the disease, ordeals and consequences. It should be taken into account almost all were written by ecclesiastics. That make easier to understand their attitude towards epidemic, for they considered a disease to be a punishment for sins, in accordance with actual teachings. From that starting point, those who were not infected considered that God's blessing, while among "sin- 
ful" Catholics they always recorded that disease is advancing or, as they wrote in one of the letters "Our people are healthy, while Croats die" [18].

As already emphasized, physicians were aware that regions, settlements or houses that contain infected people must be isolated to avoid spreading of plague and higher mortality rate. Although nowadays such measure appears inhuman for those infected were by isolation left to their fate, that was the only practical action that could stop the epidemic. Therefore, the first measure when plague appeared in vicinity of some settlement was its closing, first to prevent entering of strangers, and later to prevent exiting of local people, or all of those that happened to be in the settlement, primarily when cities are regarded. Only when medical committee was convinced somebody was healthy and there was no epidemic in the city, an individual was allowed to leave city with a passport, i.e. certificate that person was not infected. All of these measures were visible in urban centres, even in Taban, Serbian part of Budim. In September 1738 local Serbs still did not understand dangers from epidemic, but city was already closed. Serbs were not sure why this measure was established, was it from fear of uncertain outbreak of disease that foreigners could bring, or was it a measure against possible spies, for at the time the war was raging against Ottoman Empire. By mid-September of 1738 they didn't seriously faced the epidemic, but situation south of Budim was getting tougher and it was obvious the disease was approaching. [19] In Budim, just next to Serbian settlement, below Gelert hill a quarantine was established with houses for doctors and priests that were supposed to take care of spiritual needs of infected and provide service to the dying. [20] In December 1738 all settlements around Budim were closed and it was ordered that all communication between them should stop. [21] At that time the plague arrived to Serbian settlement, in some families everyone died and their houses were torched, while in others, where there were some uninfected people, only the most dangerous objects were destroyed. Anyway, the number of dead was not large. [22]

The answer to such developments was firmer control, ban of movement and extraction of suspected from healthy ones. That helped to bring plague among Serbs in January 1739 to low levels. Guards were given authority to kill anyone who would attempt covertly to enter or leave city. Sanitary services were functioning well and as soon as somebody became ill he was taken out of city and into quarantine under Gelert hill. By the middle of January in it were just three Serbs, but even they were healthy. Before February 7 commissars came to Taban with doctors and started revitalitization of all houses. Soon they concluded there were no more infected. In the whole city by mid-February were found only four sick people, and they were not infected by plague. Citizens of Budim hoped ban of movement would soon be lifted. [23] Anyway, the plague was not eradicated, it was still present in vicinity of city and any movement could bring it back to life. In one of the reports it can be seen that in first wave of epidemic not many Serbs died - 27, and those were mostly drunkards, tramps, poor people and even for those it is not known did they all suffered from plague. People were moving less not only because of guards and fear of disease, but 
also because of winter. Serbs thanked God for small casualties, believing he saved them because of numerous processions, fervent prayers, vigils and anointing with myrrh, although actually presence of many citizens in small space on these occasions could provoke spreading of epidemic. [24-25]

The plague, anyway, was just beginning to spread. Priest Nikolaj Milovanović soon realized disease appeared among relatives and neighbors of deceased persons, and informed his superiors about that. [25-26] At the end of February 1739 the decree was reissued that no one can leave Budim and its vicinity without passport, and that citizens inside city should mix as little as possible. [27] The first signs of spring and movement of population brought about new wave of epidemic. In Serbian settlement, fortress and Budim foothill the situation was difficult, for because of banned entering and exiting city citizens could not provide food and fuel. [28] Hunger and cold were reasons that caused rebellion at the end of March. Although it is not fully clear how it started or where, it quickly reached Taban. Rebels attacked medical personnel and gave them such beating that some died on the spot, some soon afterwards. Among the dead was doctor Meisner, imperial physician who was taking care of infected. Serbs claimed they had nothing to do with that event, although priest Nikolaj Milovanović in his letter to bishop Vasilije doubted that claim. $[25,29]$ The authorities sent army to Taban, with orders to apprehend perpetrators and prevent new rebellions. Decision was made that new medical personnel should be sent only after enquiry was finished and culprits punished. A commission was sent that included four executioners whose task was to execute all those who violate prohibition of leaving their homes and city. Clergy noticed straight away that death of medical personnel and rejection to bring new one were prime causes of new wave of epidemic, for people were moving through city freer than before [30].

In May movement restriction was mandatory for everyone in Taban, for plague was spreading among Serbs [31]. Even contemporaries were aware that it resulted from the fact physicians were killed, so there was no one to separate them from those infected or to cure them. Priest Nikolaj Milovanović noticed that mixing of population brought about spreading of epidemic for they transferred plague one to another, and during May in quarantine below Gelert hill there were no bearers and doctors, so conditions there were very bad. Following order of secular authorities clergy appealed to citizens not to leave their houses, not even to come to church [32].

Plague spread even to surroundings of Budim. By June 1739 it took many lives in Pomaz, while in main bishop's residence - Sentandreja - it was absent. [33] In April closed were all urban settlements surrounding Sentandreja - Budim, Ostrogon (Esztergom), Vac (Vác), and villages Pomaz, Kalaz (Budakalász) and Čobanac (Csobánka). [34] The proportions of epidemic in Pomaz are best described by the fact that citizens of Sentandreja recorded that due to wind blowing towards their settlement one can feel indescribable stench from unburied human corpses [35]. The village was severely hit by epidemic already in March, and that is why guards were posted all around its territory, but there are no records of medical personnel inside 
it. It was left to its destiny. Since not even mail could leave it, all testimonies describing its ordeal are from second hand, primarily from citizens of Sentandreja. Having no possibility to leave settlement, villagers could not cultivate their land and vineyards, so hunger was a constant threat. That was beginning of huge ordeal of Serbs in Pomaz. In June there were dying three to five persons per day, something that is very high rate for a village population. [36] Because of hunger in Pomaz, citizens of Sentandreja started to make bread and, since they could leave their settlement, they were used to take it to village territory where someone from Pomaz could retrieve it later. [37]

The fear of death and epidemic was felt during May in Sentandreja, for infected people were in all surrounding settlements. At the moment they were reporting that to the bishop (May 1739) the plague was already among them, for in a postscript priests described symptoms of disease with one of "masters" they called Paprika (Pepper), who had bumps on his body, consistent with plague symptoms. They predicted he would stay alive for two days at best. [38] The guards around the settlement by the end of May and beginning of June didn't let through even mail, and they could kill anyone trying to leave or enter the town. [39] The measures imposed in Sentandreja, primarily isolation, helped to prevent mass spreading of plague in the settlement. [40] Citizens of Sentandreja closed their settlement themselves, and specially carefully guarded sides towards Pomaz and Čobanac in Piliška hills. There were altogether five guarding posts. [41]

In order to prevent spreading of epidemic in Taban, new bearers for infected and dead were appointed as were doctors under Gelert hill, and with them came orders to bury dead in detached place. Situation was getting worse, as shown by the fact that just at that time in quarantine died Serbian priest Vasilije, and was replaced by Jakov Popović who had same destiny laying in store for him. At the same time, with consent from authorities people spread to woods, cottages and vineyards. That measure denotes extremely hard situation. [42] The infection was at its peak during May and June before doctors arrived, for then in Budim were dying daily 20 to 25 Catholics and 4 to 6 Serbs, although there were days when that number went up to ten. By the beginning of August plague was abating although still present, each day one or two persons were dying, rarely three. $[25,43]$ By the end of August it was known special envoys will visit infected settlements and in homes where there were infected or everyone died apply sanitary measures, burn clothes, wash and smoke houses to eradicate disease and make buildings usable again. [44] At that time epidemic was very intensive in villages, so guards were posted at roads to prevent movement, especially entering cities. Before autumn picking of products Budim magistrate allowed exiting city, but to prevent much contact between people certain periods were assigned to each part of the city. [45]

Even more difficult situation than the one in Taban was in Pomaz, where until August 1739 died some 400 people. [46] For Transfiguration (August 17, 1739) citizens of Sentandreja brought to Pomaz territory food and in the evening they met Jo- 
van Bešlić, the first person they saw and approached since outbreak of plague in that village. They left shocking description of that encounter: „We were horrified when we saw him. We couldn't recognize him for a long time [...] he was overgrown on his cheeks and had a big beard, only eyes and nose could be seen. As if he spent ten years in a dungeon. It was due to huge sorrow for his sons and brother. We began to question him [about plague and death - author's comment] but he didn't say a word [about that - author's comment], just bended to the ground sobbing and crying. We couldn't talk anymore, but seeing that big sorrow we also started to cry". [47]

While on one side caution of Sentandreja citizens stopped disease at the door of their settlement, imprudence of single person could have brought serious consequences. Only alertness of leading people saved Sentandreja in that challenge. Actually, towards the end of August 1739 certain Boško from Sentandreja despite the ban managed to enter Pomaz where he, probably for food he promised to provide, took from villagers 200 forints. He was infected on that occasion and soon after his return to Sentandreja became sick and died. On the fifth day after his death his wife got in touch with the money brought from Pomaz, became sick and died several days later. Same fate fell upon Boško's younger brother, and subsequently another seven households contracted plague from them. In such grave circumstances all infected houses were isolated, and Boško's one was burnt. In the meantime died Boško's youngest brother and his wife, while wife of middle brother, servant and a baby were not infected, but had to endure quarantine. Only quick reaction of Sentandreja citizens prevented larger catastrophe in their settlement. [48]

An ease was felt in Taban in November 1739 when it became obvious epidemic is abating. It appeared sporadically among Serbs and Catholics, but less and less so and there were cases of healing. For security reasons prohibition of leaving settlement was still in place. In order to prevent movement of population, authorities closed churches and kept strong sentinels throughout town to prevent movements within. Abating of plague can be seen also from the fact that archpriest Nestor Živanović started to perform weddings in October. That same pries informed bishop in Budim that that far died 631 people of Orthodox denomination, while there were 5,865 dead in whole city. In Pešta (Pest) there were 620 dead. $[9,49]$ Number of Orthodox victims in Budim made $10.76 \%$ of total of those who died during epidemic. It remains unknown, anyway, how many Serbs lived in the city at the time. Fifteen years after these events Budim and Pešta had together 185 Serbian households, and that clearly explains how grave was epidemic 1738-1740. The three villages with lot of casualties - Pomaz, Kalaz and Čobanac - on that same year had altogether 191 households. Those are, of course, households that survived plague. How many perished in the plague remains unanswered question. [18] There are not many precise data on number of dead during the epidemic, so it is difficult to assess what percentage of them made Serbs. At the very beginning of 1740 doctors visited Sentandreja and declared the disease is no longer there, but they didn't go to Pomaz for plague was still present there. [50] By the end of February still no one was allowed 
into Budim and information were that it will be allowed only in May if there were no new cases of disease, for plague was still present in surrounding villages. Yet, Budim was open already in March 1740, since there were no serious threats in its vicinity. $[25,51]$

The fate during plague epidemic 1738-1739 of population of settlements within barely twenty kilometres - Taban, Sentandreja and Pomaz, showed all advantages of applying measures against spreading of disease and all consequences of lack of their understanding or accepting. Also, it shows that situation and opinion of Serb population was the same as in other nations. The plague provoked fear, so after first fatalities people took refuge from it through isolation, either individual or imposed, but made mistakes during church processions for their gathering in one place only boosted spreading of disease, so consequently such gatherings were prohibited. Isolation lead to hunger and, in winter months, to freezing and that, in periods when plague was abating or almost absent, led to conclusion ban of movement was redundant and medical personnel are main culprits for all the problems. Such opinion brought about lack of discipline and, eventually, attacks on doctors. Those under Gelert hill especially had lot of casualties, but that was not the only settlement with such a fate. Such situation led to high mortality, and culprits were exactly those who lacked discipline and understanding. On the other hand, Sentandreja is just the example of a different fate. Once news spread on approaching disease its inhabitants on their own closed their settlement and imposed guarding post that controlled all approaches to the town. By that they prevented more serious consequences. When, due to recklessness of an individual the plague yet entered Sentandreja, quick reaction and isolation prevented it to spread to larger number of people. That showed also how lack of cooperation or recklessness of a single member of Serbian community could bring disaster to whole settlement, or how unanimous action could prevent it. Finally, the third example - Pomaz - depicts population that was left on its own and reveals tragedy of rural population that was isolated, with no medical personnel, and was dying of hunger, freezing and plague. Here was vividly described one personal tragedy, although certainly there were lots of those, but in many cases nothing was noted except for number of dead. Many settlements needed lot of time to recover from this epidemic, and Serbian population in them, like for instance in Pomaz, was permanently decreasing in numbers and its perishing was accelerated.

\section{Rezime}

Razvoj ljudske civilizacije praćen je pokušajima da iskorene zarazne bolesti, kao što je kuga, koja je kroz istoriju imala značajno visok letalitet. U tom smislu, tokom 18. veka je u Habzburškoj monarhiji donet značajan broj propisa kojim se pokušavalo sprečiti širenje epidemija. Svi ovakvi propisi su u velikoj meri bili u suprotnosti sa narodnim običajima i verskom praksom sahranjivanja. Epidemije kuge u Budimu, Sentandreji i selu Pomaz, od 1738. do 1740. godine jasno ilustruje upravo posledice koje je po širenje zaraze imala primena tadašnjih sanitarnih mera, kakve je posledice ostavilo njihovo kršenje i koji je sve to imalo 
učinak na stanovništvo. S jedne strane, preduzete su mere za borbu protiv epidemije, a sa druge, ubistvo lekara u Budimu je sve dobre namere anuliralo i dovelo do velikog pomora stanovništva. Tamo gde lekara nije bilo, kao u Pomazu, posledice su bile još teže, dok učinak kuge gotovo da se nije osetio u Sentandreji gde su poštovali sve naredbe i sanitarne propise. U značajnom broju arhivskih dokumenata nalazimo podatke o epidemijama, načinu lečenja, broju obolelih. Analiza arhivskih dokumenata i mnogobrojnih natpisa u štampi svedoče o problemima sa kojima se srpsko društvo u Monarhiji suočavalo tokom epidemija. Efikasno suočavanje sa kolerom poticalo je od nadležnih državnih institucija i baziralo se na tadašnjim metodama lečenja, o čemu postoje mnogobrojni podaci i samih učesnika.

\section{References:}

1. Todorović K. Kuga [Plague]. u: Medicinska enciklopedija. IV. Jugoslovenski leksikografski zavod; 1969: 187-194.

2. Heidel S. Die Pest in Europäischen Städten. Chemnitz: Technische Universität Chemnitz; 2006: 6-8.

3. Bailey D. The plague. New York: The Rosen Publishing Group; 2011: 22-43.

4. Schmeichler N. Reaktionen auf die Pest: Die Neuzeit entsteht, Hamburg: Bechelor Master Publiscing; 2013: 5-28.

5. Vaniček F. Spetialgeschichte der Militärgrenze. I. Wien: Aus der kaiserlich-königlichen Hof-und Staatsdruckerei; 1875: 161-163.

6. Schwicker JH. Geschichte der österreichischen Militärgrenze. Wien und Teschen: Verlag von Karl Prochaska; 1883: 103-112.

7. Микавица Д, Лемајић Н, Васин Г, Нинковић Н. Срби у Хабзбуршкој монархији пд 1526. до 1918. [Serbs in Habsburg Monarchy 1526-1918]. Нови Сад; Прометеј; 2016: $212,216-225$.

8. Поповић Д, Сечански Ж. Грађа за историју насеља у Војводини од 1695. до 1796 [Materials for the history of settlements in Vojvodina 1695-1796]. Нови Сад: Матица српска; 1936: 49-60.

9. Dávid Z. Az 1738, évi pestisjárvány pusztítás. Orvostőrténti Közlemények. 1973: 75-79, $89,129$.

10. Гавриловић С. Срем од краја XVII до средине XVIII века [Syrmia from the end of $17^{\text {th }}$ to the middle of $18^{\text {th }}$ century]. Нови Сад: Филозофски факултет; 1979: 237-265.

11. Vekerdi L. Magyarországi és Erdélyi pestisjárványok a XVIII. Században. Járványtőrténeti bibliográfiai függelékkel 2009: 8 .

12. Васин Г, Нинковић Н. Смрт између санитарних прописа и народних обичаја: куга у Срему 1795-1796 [Death between sanitary regulations and folk customs: plague in Syrmia 1795-1796]. Зборник Матице српске за друштвене науке. 2015;151:277-281.

13. Васин Г, Божанић С, Кисић-Божић М. Неадекватно сахрањивање као важан фактор у епидемији куге код Срба у Хабзбуршкој монархији крајем 18. века [Inadequate burials as an important factor in the epidemic of plague among the Serbs in the Habsburg monarchy in the late 18th century]. Српски архив за целокупно лекарство. 2014;11/12:764-767. 
14. Гавриловић С. Епидемија куге на Балкану и средњем Подунављу од краја XV до XIX века [Plague epidemic in the Balkans and middle Danube region from the end of $15^{\text {th }}$ to $19^{\text {th }}$ century]. Зборник радова: 200-годишњица сремско-иришке куге. 1996: 7-13.

15. Kun E. Mutogattya isten haragját - Adelékok az 1739/1740-es Debreceni pestis Történeténez. Hajdú-Bihar Megyei Levéltár Évkönyve. 2002;XXIX:69-78.

16. Öri P. A pestisjárványok demográfiai kövertkezményei a 17-18. századi Magyarországon. A KSH Népességtudományi Kutatóintézet Történeti Demográfiai Évkönyve. 2005: 115-117.

17. Илић Ј. Банатска војна крајина у другој половини 18. века [Banat Military Frontier in the second half of the 18th century] [необјављена докторска дисертација]. [Београд]: Универзитет у Београду; 2014: 48-52.

18. Гавриловић В, Васин Г, Нинковић Н. Преглед историје Будимске епархије до 1918 [Review of the history of Buda Eparchy to 1918]. Три века Карловачке митрополије 1713-2013. 2014: 103-109.

19. Архив Српске академије наука и уметности у Сремским Карловцима, Митрополијско - патријаршијски архив, Фонд „Б“ [Archive of the Serbian academy of sciences and arts in Sremski Karlovci, Metropolitan - Patriarch archive, Fond "B”] (у даљем тексту: АСАНУК, МПА „Б“) 65/1738.

20. АСАНУК, МПА „Б“ 59/1738.

21. АСАНУК, МПА „Б“ 74/1738.

22. АСАНУК, МПА „Б“ 95/1738.

23. АСАНУК, МПА „Б“ 137, 138, 140. и 141/1739.

24. АСАНУК, МПА „Б“ 63/1739.

25. Поповић Д. Срби у Будиму од 1690 до 1740 [Serbs in Buda 1690-1740]. Београд: Српска књижевна задруга; 1952: 361-362, 364, 366, 369.

26. АСАНУК, МПА „Б“ 142/1739.

27. АСАНУК, МПА „Б“ 92. и 93/1739.

28. АСАНУК, МПА „Б“ 160. и 161/1739.

29. АСАНУК, МПА „Б“ 18/1739.

30. АСАНУК, МПА „Б“ 194/1739.

31. АСАНУК, МПА „Б“ 68. и 91/1739.

32. АСАНУК, МПА „Б“ 144. и 145/1739.

33. АСАНУК, МПА „Б“ 52. и 54/1739.

34. АСАНУК, МПА „Б“ 105, 162. и 164/1739.

35. АСАНУК, МПА „Б“ 163/1739.

36. АСАНУК, МПА „Б“ 143/1739.

37. АСАНУК, МПА „Б“165. и 166/1739.

38. АСАНУК, МПА „Б“ 151/1739.

39. АСАНУК, МПА „Б“ 152/1739.

40. АСАНУК, МПА „Б“ 153/1739. 
41. АСАНУК, МПА „Б“ 154, 164. и 165/1739.

42. АСАНУК, МПА „Б“ 45, 47. и 146/1739.

43. АСАНУК, МПА „Б“ 116/1739.

44. АСАНУК, МПА „Б“ 117/1739.

45. АСАНУК, МПА „Б“ 119/1739.

46. АСАНУК, МПА „Б“ 166/1739.

47. АСАНУК, МПА „Б“ 166/1739.

48. АСАНУК, МПА „Б“ 167. и 168/1739.

49. АСАНУК, МПА „Б“ 69-76, 80-85, 89, 90/1739.

50. АСАНУК, МПА „Б“ 171/1739.

51. АСАНУК, МПА „Б“ $84,85$. и 8I/1740.

Submitted: 20. 10. 2016. Reviewed: 29. 10. 2016. Accepted: 11. 11. 2016. 